\title{
Special Collections in the
}

\section{College Library}

$\mathrm{T}$ HIS Is A "case history" report $^{1}$ on six special collections at Swarthmore, as samples of activities that illustrate modest ventures in which college librarians may share as bookmen. These collections fall into three categories or degrees of relevance to our major responsibility: (1) those which are integral in the fabric of the college's history and philosophy; (2) those tied by some associative thread to college interests, and providing materials beyond the strict demands of curricular necessity; and (3) those which have come to the college fortuitously and by external chance. The two collections in the first category are an essential obligation upon us; two in the second group provide a highly desirable extension and enlargement of resources related to the intellectual aims and instructional purpose of the college; about the remaining two in the third group I have my dubieties.

\section{FriendS Historical Library}

The Friends Historical Library-our basic, oldest, and largest special collection-had its inception in the religious affiliation of the college's founders. The Quakers, with their fundamental and continuing concern about peace, have paradoxically produced or provoked during three centuries a stormily controversial and voluminous literature. Our state's patron, William Penn, who attached himself to the Society of Friends

1 Paper presented at Eastern College Librarians Conference, November 26, 1956, Columbia University. New York.

Mr. Shaw is librarian, Swarthmore College. in 1667 when he was twenty-three, was committed to the Tower of London for his unorthodoxy when he was twentyfour; and, at the age of twenty-five in the Tower, wrote his learned and eloquent dissertation on the Christian duty of self-sacrifice, No Cross No Crown. This was by no means the first Quaker book. George Fox, founder of the Society, had begun his preaching and writing two decades earlier. Almost ninety years ago Joseph Smith (not the Mormon dignitary) produced a two-volume bibliography of writings by and about Friends and in the span of about the next quarter-century also published a 364-page supplement and a 474-page Bibliotheca Anti-Quakeriana.

In this country, as the nineteenth century started into its second quarter, the Society of Friends indulged in an unQuakerly quarrel that resulted in a denominational split. Elias Hicks, perhaps best identified to non-Quakers as a cousin of the primitive artist who painted The Peaceable Kingdom, led the schism from which came the sect known as the Hicksite Friends. The Quaker eastern colleges for men and women, founded respectively in 1833 and 1885 by the Orthodox Friends, are Haverford and Bryn Mawr; Swarthmore is the coeducational college started by the Hicksite Friends in 1864. The two not-quitewarring but not-quite-amicable branches of the Society have recently reunited. Quakerdom has emerged a peaceable democracy.

The Philadelphia area has a rich concentration of material by and about Friends and their activities-their ef- 
forts toward peace, toward bettering race relations, toward improving prison conditions, and other Quaker concerns. Stemming from the one root in England, but pursuing the divergent branches developed in America, two small colleges (Haverford and Swarthmore) each under the outstandingly competent guidance of historian-librarians have amassed special collections including books, pamphlets, journals, manuscripts, letters, archival records of meetings and associations, microfilms, clippings, photographs, genealogical records, and special indexes that together (or only eight miles apart) probably equal or perhaps excel any other Quaker collection in the world. The Friends Historical Library, a separate entity at Swarthmore, contains about twenty thousand books and pamphlets; manuscript boxes occupying more than 150 linear feet of shelving; and receives currently about 130 Quaker periodicals. Haverford's Quaker collection is about the same size.

From this treasure-house it is (adopting, I fear, a highly inappropriate analogy) as difficult to select a top ten items deserving citation as it may well be to choose from the total bevy of beauties the ten finalists in Atlantic City's annual Miss America contest. Here is a selection of diverse Quaker entries, attractive through age, rarity, or utility: (1) with occasional cuts in the luxuriously flowing language of its seventeenth century titlepage, the 1694 first edition of The Journal or Historical Account of the Life, Travels, Sufferings, Christian Experiences and Labour of Love in the Work of the Ministry, of that Ancient, Eminent and Faithful Servant of Jesus Christ, George Fox; (2) three holograph versions of John Woolman's 1774 Journal; (3) photographs of some 650 meeting houses; (4) the 1669 first edition of Penn's No Cross No Crown; (5) Jane Addams's personal correspondence dealing with her activities in peace move- ments, books from her personal library, and the gold medal given her with the Nobel peace award in 1931; (6) more than four hundred autograph letters of Lucretia Mott, antislavery and women's rights leader; (7) over a thousand record books (dating back to 1665) of Friends Meetings; (8) 210 card index drawers of the Hinshaw genealogical analysis of Quaker meeting records; (9) more than four hundred letters of Elias Hicks; and (10) a collection of Whittier first editions and manuscripts.

\section{SWARTHMOREANA}

For every college an institutional particularization which exemplifies the collections in our first category is its assemblage of "ana"-Amherstiana, Bowdoiniana, Columbiana and on through the alphabet. No other place in the world should be able to supply as completely and conveniently as its own college library the materials (both the major items and the minutiae) published by and about an institution and by and about its past and present personnel. Complete files of catalogs, annual reports and other official publications; class yearbooks, the college newspaper, and the literary magazines; books and articles by the faculty and alumnithese are the staple items in such collections. The collections are, however, capable-and probably deserving-of great expansion in their inclusions. A sample half-dozen additional preservations in the "ana" holdings might include: (1) the correspondence of presidents, distinguished professors, and perhaps even more distinguished alumni; (2) records from the offices of the registrar and the deans-perhaps reduced to microfilm; (3) programs of public events at the college; (4) financial and business accounts and records; (5) tape recordings of student plays and concepts, and (6) files of examination questions.

For arranging Swarthmoreana we 
have adapted and itemized a few numbers in the Library of Congress classification. Books by alumni, for example, are chronologically arranged by the author's year of graduation. For many new publications we try first, through personal solicitation, to obtain an inscribed gift copy. Intimations of additions come from various sources: faculty members who report a book or an article by a former student, a note from our alumni office, an unheralded gift from the author. Those of us who check bibliographies or catalogs have developed an uncanny (or canny) knack in spotting Swarthmore names. We set aside in the annual budget a modest amount for purchasing books in this field.

The collection occupies over two hundred linear feet of shelving. A detailed account of our holdings would be dull to non-Swarthmoreans; but for any college librarian there would be a pleasure equivalent to mine in receiving from his Jim Michener the gift of forty volumes of his seven books in ten languages; or in finding on his desk a gratefully inscribed copy from a former student assistant who has rocketed to the top in the new field of automation; or in receiving from a stranger a letter written on Atlanta hotel stationery and enclosing what he had found in a volume just purchased at a second-hand bookstorean 1888 letter which a Swarthmore freshman boy had written home reporting (what in 1956 seem the extremely mild and innocuous) pleasures of college life, and asking for more money and another cake.

\section{British Americana}

By acquired association it became appropriate for us to establish and maintain the special collection which is our second category's first example. During the incumbencies of two college presidents, Swarthmore has been the home of this country's office of the Rhodes
Trust. The Anglo-American ties are strong.

Eighteen years ago we began to collect and segregate the accounts of travels in the United States that were written by English visitors here. This is our British Americana collection.

Here, too, we have adapted to the unusual circumstances a small section of the classification scheme. Usual classification is abandoned: the books are arranged in chronological order by date of the visit described; and on contiguous shelves will be found observations on such diverse matters as slavery, wild life, theatrical affairs, geology, sports, agriculture, Indians, religious life, military activities, and politics. Included as supplementary parts of the collection are a few bibliographies, novels based on their authors' travels here, biographies of the authors, and accounts of travels that cannot be precisely dated.

These editions of 1,174 titles are a fascinating array of books. The foundation volume is Thomas Harriot's $A$ Briefe and True Report of the New Found Land of Virginia. We can never aspire to a first edition (there are, I think, only five perfect copies known to exist) but we have three reprint editions. From this 1585 account the procession of travellers' tales extends to four new titles published this fall. We try to keep the collection up to date; and from the older titles we have acquired nearly all that we know to be appropriate except those that are rare and costly collectors' items: books which it seems improbable that we can ever afford. Fortunately we have a few of even these.

In tone the books range from the highly vituperative to the equally gracious. Here is, for example, Mrs. Frances Trollope's account in The Domestic Manners of the Americans of being a guest at a dinner party in the late 1820 's.

“. . . whatever may be the talents of the persons who meet together in society, the 
very shape, form, and arrangement of the meeting is sufficient to paralyze conversation. The women invariably herd together at one part of the room, and the men at the other.... The gentlemen spit, talk of elections and the price of produce, and spit again. The ladies look at each other's dresses till they know every pin by heart; talk of Parson Somebody's last sermon on the day of judgment, on Dr. T'otherbody's new pills for dyspepsia, till the 'tea' is announced, when they all console themselves together for whatever they may have suffered in keeping awake, by taking more tea, coffee, hot cake and custard, hot cake, johnny cake, waffle cake, and dodger cake, pickled peaches, and preserved cucumbers, ham, turkey, hung beef, apple sauce, and pickled oysters than ever were prepared in any other country of the known world. After this massive meal is over they return to the drawing room, and it always appeared to me that they remained together as long as they could bear it, and then they rise en masse, cloak, bonnet, shawl, and exit."

An agreeable contrast is found in these sentences written a century or so later which tell about a British visitor's stay at Swarthmore (Walter Wilkinson. Puppets Through America. Bles, 1938).

"We drew up within the precincts of the college, walked under a deep arch and found ourselves in a delightful green quadrangle surrounded by greystone Cotswold cottages. Entering one of the cottages by a heavy oaken door we deposited our bags in our home for the next ten days, a long Cotswold bedroom with low sloping roof and dormer windows all complete. We looked down into the quadrangle and out to the rising green campus where the many handsome buildings stood among the trees. It is a college in the country, a very civilized country, with a railway station on one corner of the campus, and a small town with its restaurant furnished with colonial antiques, a book store-all the amenities, in fact, with the ubiquitous drug store richly stocked with light refreshments, journals, tobaccos, and all human needs, much as you would find in New York. This literature business be- gan almost unawares over coffee and cake in the professor's living room, a large handsome room with a rocky hearth fireplace, Persian rugs and white paint, and comfortable chairs. Some seven or eight young ladies and one man, in very summery costumes, carried on a pleasant and intelligent discussion, subtly guided by the professor, on the works of Conrad. They had all had more time in which to read Conrad than I had, and I contributed to the discussion the golden quality of silence. From this we went to dinner in college, to introductions, and to coffee at a brief after-dinner dance for the students. . . . After dinner we made an exodus under the trees and bright stars to another professor's living room. Here students read and discussed their original stories and poems. ... After all these new experiences we suddenly realized that we had only been in the States exactly one week, and that we had been wafted on from one thing to another in a state of perfect enjoyment. The weather was so fine ...; the world was so dry and radiant with sun, and now the almond trees and daffodils were out on the Swarthmore campus, the maple trees were covered with green knobs, and the Japanese cherries with white buds. Here and there students would be sunning themselves on the grass, and they seemed to me very fortunate young people, with their great freedom, the friendly co-operation of their professors, and the beautiful spring-nurtured campus in which to wander."

The final paragraph in an introductory "Bibliographical Note" to a Columbia dissertation (Max Berger. The British Traveler in America, 1836-1860. Columbia Studies in History, Economics and Public Law No. 502, 1943.) says: "The travel books of Britons who visited America a century ago are no longer in general circulation. In fact comparatively few libraries contain large collections of such works. The New York Public Library has the most complete file. The Library of Swarthmore College has a special collection of British Americana. Columbia University Library and the 
Library of Congress also have good collections in this field." In any comparison, to place second after the New York Public Library and to rank ahead of Columbia and the Library of Congress gives pleasurable eminence to a small college library and is a rewarding recognition of this special collection's at least occasional usefulness and value.

\section{Presses}

The second example in our second category is one which both very generally and quite specifically enriches the library's resources beyond the demands of meeting curricular requirements. Its existence is based on two premises: (1) that in such arts as music, painting, and literature a college tries to cultivate and improve the taste of its students above rock and roll, comic strip pictures, and westerns; and (2) that students continually_well, frequently-handle books and scan printed pages. If, in their experience, we try to substitute Chopin Preludes for Elvis Presley, Picasso for Petty, or to change reading tastes from William MacLeod Rains to Rainer Maria Rilke, it seemed logical and desirable to attempt in printing - "the art preservative of all the arts"- to acquaint our students (and perhaps ourselves) with fine typography's delights and rewards.

It was with these convictions that we started twenty years ago to assemble a special collection of the productions of private presses and other examples of fine printing. The collection now extends to some 2,350 titles and contains representations of work from 322 American, 104 British and 25 other presses: over 450 fine-printing organizations display their wares for us. A modest income restricts most of our purchases to contemporary presses, but we do not scorn pre-twentieth century printing: I suppose that our most gratefully welcomed private press gift is the magnificent fivevolume Doves Press Bible.

The names alone of the presses are a dazzling conglomeration of colors, birds, beasts and flora; of wit, allusiveness, description, and incongruity. Here from the hundreds of names are a few: the Black Cat and the Lucky Dog; the Hobby Horse and the White Elephant; the Blue-behinded Ape and the Rampant Lions; the Woolly Whale, the Bronze Snail and the Hiccupy Herring; the Redcoat and the Roving Eye; the Green Horn, the Gray Moose and the Golden Eagle.

By another local adaptation of the classification scheme we disregard subject matter and shelve together the books which come from each press: our few Kelmscotts and our many Peter Paupers each stand assembled as units in the collection.

Most of the volumes in this collection are literary works, but the books are all-encompassing, stretching even to such scientific inclusions as Mary Vaux Walcott's five-portfolio set North American Wild Flowers, published by the Smithsonian Institution in 1925, with typography by Frederic W. Goudy; and Herbert Hoover's 1927 address $A$ Remedy for Disappearing Game Fishes - at least there is some science in this whimsical bit of persuasion.

Many little things give us intriguing titles by the score: The True Ballad of the Galloping Hearse; Blood on the Dining Room Floor; Born in a Beer Garden; The Neurotic Nightingale; There Is Nothing, Only Cold Gray Mist.

Typographically as well as textually they are a delight, with their diversity of fonts; their span from classic austerity to modern freshness and audacity of design; their handsome craftsmanship; their bindings which range from sheet copper or aluminum to burlap, from such unusual leathers as kangaroo and 
sealskin to papers such as comic sheets, wallpaper or maps.

Eminent typographers and artistsWill Ransom and Carl Rollins, Richard Ellis and Joseph Low-have visited it. Many practicing printers from our area come to consult it. The Philadelphia Graphic Arts Forum has travelled out from the city to hold three meetings in the library and to browse delightedly among these treasures. In the college's extra-curricular arts and crafts program those students who are amateur printers and are adept at setting their own type and running off their own composition on the two printing presses provided for them, find it an absorbing hunting ground for ideas and styles. Belles lettres for our small exhibit cases are in almost unlimited supply: half a dozen printings of Clement Moore's A Visit from Saint Nicholas to precede the seasonal vacation; a show from American, English and continental presses of Keat's Odes; another startlingly diversified group of Lamb's A Dissertation upon Roast Pig; or again half a dozen quite different but all sparkling editions of The Rubaiyat of Omar Khayyam.

\section{EDITIONS}

John Edwin Wells was best known in the scholarly world for his Manual of Writings in Middle English, 1050-1400, published in 1916, with eight Supplements appearing through 1941. He was graduated from Swarthmore in 1896, and received his M.A. from Columbia in 1900 and his Ph.D. from Yale in 1915. Following a decade of teaching at Hiram College and seven years at Beloit, he went to Connecticut College to head its English department in 1917, and remained there until his death in 1943. He had not, so far as I was ever able to ascertain, maintained any Swarthmore ties; but his will bequeathed to our library two special collections which he had assembled and nurtured with loving devotion.

They are small but almost complete collections of all editions from the first to present-day printings of the works of two English poets; James Thomson and Wordsworth. With the books came Professor Well's own annotated card catalogs of the gifts. The collections also include critical works and biographies; portraits; transcripts and photostats of letters; musical settings of poems; and for Wordsworth, the major bibliographies, dictionaries, concordances, maps, guides, views, and books about the Lake District; and a dozen volumes from the poet's own library. Each collection also contains about a score of critical articles, written by Mr. Wells, on the poet.

These collections have brought to us, for example, a visitor from Cornell with questions that could be answered only by his examination of the Wordsworth books (a visitor who wrote on his return home: "I was prepared to see a fine collection, but I was simply astonished at its range and depth. I shall shout its praises to all who will hear.") and a correspondence with the English scholar and editor, Helen Darbishire, who requested photostats of two unpublished Wordsworth letters and permission to include these letters in a supplementary volume of the poet's letters which she is preparing for the Clarendon Press.

My doubts about these two examples from our third category of special collections do not stem from any faults or weaknesses in the collections. They are gems of their kind. My question is rather concerning their appropriateness in a small college library. Each provides an almost unique wealth of resources far beyond the needs of undergraduate students. They are inestimably valuable concentrations for the specialized scholar, but it may be that only by chance will the scholar know of their existence

(Continued on page 517) 


\section{Special Collections in the College Library}

(Continued from page 484)

at Swarthmore. Their greatest usefulness would place them in a large and central library amid a huge array of pertinent primary documents, associated biographies, critical monographs, and the bibliographical apparatus needful in correlating and evaluating discoveries and conclusions. . . . But, I confess, we're grateful that we have them.

A college librarian's obvious primary obligation is to assemble, with faculty advice, and then to make serviceable to his community of actual and potential scholars, those printed and allied resources which directly support his institution's program of instruction. This is the "minimum subsistence fare," necessary, nourishing, mostly-we hope-palatable. Vast areas of written and printed documents remain, and among these are fields which comprise sorts of "fringe benefits" for our group of faculty and student associates. It is in this peripheral domain that the acquisition, preservation, careful recording, and occasional use of our special collections will fall. They are, in a way, luxuries - the raisins in the daily bread, the jewels adorning the work-worn hand, the flowers in the button-hole of a threadbare suit. They are a joy and a pride to the book-loving librarian. It is our routine to buy a dozen duplicate copies to go on reserve for History I; it is our delight and our durable satisfaction to enrich a special collection. For us no other bibliophilic thrill is quite equal to the fruition of inexpensively acquiring that patiently long-sought and elusive desideratum which alone can fill a vacant niche on a favorite shelf. Innumerable subjects and sizes of bookish ingatherings open up before us. Bibliographic vistas stretch high, wide, and handsome.

\section{New Reprints}

\section{Now Available}

\section{Chemical Reviews}

Volumes 50-51, 1952

Single volumes, paper bound

$\$ 17.50$ each

Deutsche Chemische Gesellschaft: Berichte

Volumes 1-10, 1868-1877

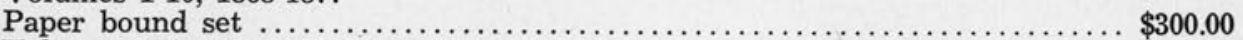

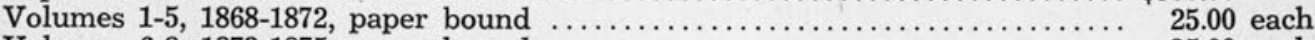

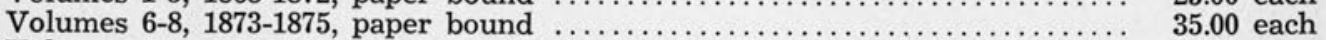

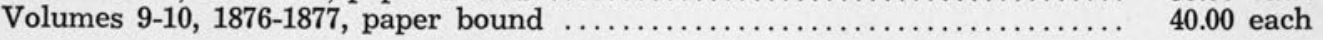

\section{In Active Preparation}

\section{Journal of Geology}

Volumes 1-25, 1893-1917

Cloth bound set (including Supplement $23 \mathrm{~A}$ and Index to Volumes 1-35) .... \$695.00

Paper bound set (including Supplement $23 \mathrm{~A}$ and Index to Volumes 1-35) ..... 650.00

Single volumes, paper bound $\ldots \ldots \ldots \ldots \ldots \ldots \ldots \ldots \ldots \ldots \ldots \ldots \ldots \ldots \ldots \ldots, 25.00$ each

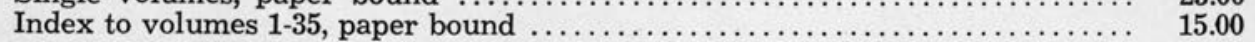

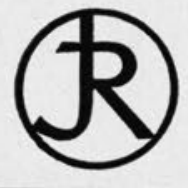

Please address orders and inquiries to

\section{JOHNSON REPRINT CORPORATION}

111 Fifth Avenue

New York 3, New York

Please mention $C$ \& $R L$ when corresponding with its advertisers. 